\title{
marketing.
}

ČLANCI/PaPERS

\section{Logistics Aspects of Goods Home Delivery: The Case of Amazon Company}

\author{
Slobodan Aćimović, Veljko Mijušković, \\ Nikola Milošević
}

\begin{abstract}
Adequate management of logistics activities is essential for the efficiency of all business activities of a company. Goods home delivery as a concept has gained prominence with the development of internet and e-commerce. During the last decade, owing to the increasingly intense IT development, it has become relevant in the contemporary logistics business. Within this concept, the temporal dimension is important, which is imposed precisely because of the demands of modern lifestyle. The average customer wants more free time, so the goods home delivery option significantly shortens the time required for shopping, leading to preference for online sellers who make delivery as a standard part of their offer. Considering the logistics aspects of the mentioned concept and its implementation on the example of a precise company (Amazon) are the basic subjects of analysis within the paper. The aim of the paper is to indicate that the modern delivery market, in addition to existing major players, is also characterized by the entry of startups, which result from entrepreneurial initiatives. The particularity of engaging entrepreneurs is to develop a new idea embodied in a business philosophy or new technological ideas, whether to solve the existing challenge or to see and take advantage of the new market opportunities.
\end{abstract}

Key words: logistics, delivery, application, time intervals, Amazon.
JEL Klasifikacija: M20, M21, O30, O32.

\section{INTRODUCTION}

Due to the internationalization and the usage of new ICT within the global market, there is a constant need for the increase in the speed flow of goods throughout the supply chain, especially within the segment of goods delivery towards the final consumer. Consequently, new business strategies and concepts are created, in order to surpass the obstacles and to meet the buyer needs in the most efficient manner possible.

Simultaneously, the demand side, reflected in the demands from the buyer, delivers the requests regarding the expected time of goods delivery. The delivery time is affected by the consumer daily needs and life style. In certain cases, it is important to fulfill the demand for goods delivery in the shortest possible time intervals from the moment of performing shopping on-line, while in other cases it is important to fulfill the demand for goods delivery in a certain time interval. The development of internet and e-commerce has had a significant influence onto the development of goods home delivery. The possibility to buy the demanded product by clicking on a button of a computer or some other smart device and then getting it delivered to the home address has resulted in a high degree of customer satisfaction. Also, the omnipresence of developed technology in the form of smart devices used by the younger generations leads to creating new consumers with habits different than those of their parents and the generations before them. The traditional task of logistics was to secure the goods at the right place, at the right time and in right quantities at certain selling points (Božić \& Aćimović, 2019), while today it is to deliver the goods at the buyer's home/business address, so the right time and place obtain a new connotation and greater importance then during the previous years.

The analysis within the paper shall try to answer the following research questions: 1 . What are the main benefits of the goods home delivery concept?; 2. How is the goods home delivery concept used on an example of a real time company and what are the conclusions that can be drawn out of that case for general business? Besides the introduction and conclusion, the very paper is divided into three parts. The first part of the paper deals with the physical flows of product (goods) delivery. The sec- 
ond part focuses on the main ideas of the concept of goods home delivery, while the third part is dedicated to concept implementation within the analysis of the Amazon business case study.

\section{PHYSICAL FLOWS OF GOODS DELIVERY}

The process starts with the buyer's decision to perform a purchase and in order to do so, the internet page or an application of the retailer is used. The order is then processed and prepared for sending. The next step is to perform the delivery. In case that the delivery is performed by the seller itself, it shall be done by its couriers. In case that the delivery is passed over to logistics providers, the provider couriers shall do it. The point of delivery can be the very address of the buyer or some other address (Van Duin, de Goffau, Wiegmans, Tavasszy \& Saes, 2016). The territory is usually divided onto smaller units according to the criteria of availability and location proximity to the warehouses and main transport routes. The warehouses are usually located within the city outskirts or suburbs (Crainic \& Montreuil, 2016).

The consolidation centers and the distribution knots especially constructed for the goods that are delivered can improve the goods distribution coordination, enabling repacking and redistribution of goods for delivery within smaller vehicles. From these centers the goods can be transported to the final destinations by small trucks and pick up vans, as well as vehicles which are more suitable for the environment, such electric cars (Foltyński, 2014), bikes and different types of autonomous vehicles and robots (Baum, Assmann \& Strubelt, 2019).

While constructing the business model and the offer, the seller must take into consideration the responsiveness of the delivery and the diversity of the products offered which influences the appearance and the structure of the distribution network (Lim \& Winkenbach, 2019). Picture 1 shows the importance of the location of the place of cargo transfer and the distribution centers. In order to make the decision concerning the design of the delivery execution, warehouse costs and transport costs must be taken into consideration. By forming several locations from which the delivery is performed, the mileage passed by vans is lowered and better customer service is secured. The average mileage per delivery is lesser and thus the delivery costs as well.

\section{PicturE 1. Model of last instance delivery}

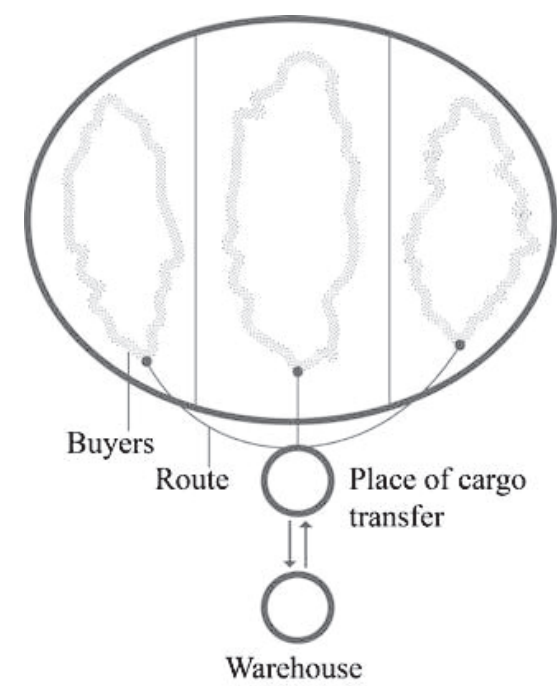

SOURCE: Dell‘Amico \& Hadjidimitriou, 2012

One of the main arguments in favor of the warehouse position within the city outskirts is the usage of big vehicle advantages for the transport on longer routes outside of the city without their shortcomings in the city area, such as pollution and transport safety risks. Within the city center the pick-up vans are smaller and go through the dense traffic more easily.

\section{GOODS HOME DELIVERY CONCEPT}

Home delivery is not connected only to internet shopping. Deliveries were performed much before the appearance of the internet, since mail was delivered to home addresses as well as bulk goods such as furniture, electric appliances, TV sets, washing machines etc. Today, even the traditional retailers have become a part of the internet shopping market by developing the internet sales channel. There are two factors which decisively influence the possibility of implementing the demands within the delivery plan: the location of the buyer and the supposed time slot within which the delivery is to be performed (Köhler \& Haferkamp, 2019). Based on these factors, buyers foresee as the main aspects of delivery: quality of service, the possibility of choosing the delivery time and the location of the delivery (Ghajargar, Zenezini, \& Montanaro, 2016).

One of the major issues concerning the goods delivery organization to the buyers within internet sales is the big fragmentation of orders. Individual buyers 
usually buy small quantities of goods and expect a fast delivery. This forces the participants of the competitive market of transport services to quickly react to on-growing demand for transport. Often, in order to satisfy the buyer's needs, commercial vehicles perform the delivery regardless of the degree of capacity usage (cargo space). Also, an issue of inadequate car park which is not adjusted to the needs of e-commerce needs to be pointed out, especially in the context of vehicle size compared to the volume of delivery.

The delivery can be performed onto the home address of the buyer, the address of a relative, work place or a neighbor as well as onto traditional places of delivery such as the post office, retail objects, check points for delivering orders etc. The selection of the delivery model which shall be used, besides the cost efficiency, depends on the expectations of the very buyers when it comes to different product categories (Madlberger \& Sester, 2005). An issue is raised for home deliveries weather it is necessary for the receiving party to be present at the moment of the delivery. Therefore, there are two goods home delivery concepts: "the delivery in the presence of the receiving party" and "the delivery in the absence of the receiving party". The presence and absence refers only to the buyer of the goods.

\subsection{The delivery in the presence of the receiving party}

When it comes to the delivery in the presence of the receiving party, the buyers must be present due to security reasons, such as good perishability, its physical size or because a service is offered (Agatz, Campbell, Fleischmann \& Savelsbergh, 2008). One of the problems faced by buyers is that there is a big time interval of the delivery and thus a long waiting procedure for the delivery arrival. In order to surpass the stated problem, companies offer services of wider time range delivery to the buyers.

The time interval for the product delivery represents a frame which can be half an hour, an hour or several hours, within which delivery is performed. The retailers create time intervals offered to the buyers as well as different fees for the delivery during those time intervals. The costs of servicing the buyer in some of the time intervals can be significantly different varying from the interval. The reason is the usage limit of certain time intervals. Due to the same reason, it can sometimes be impossible to perform the delivery to a particular buyer. In order for the usage of time intervals to be successful, the retailers must make adequate

\section{PICTURE 2. Goods home delivery costs}

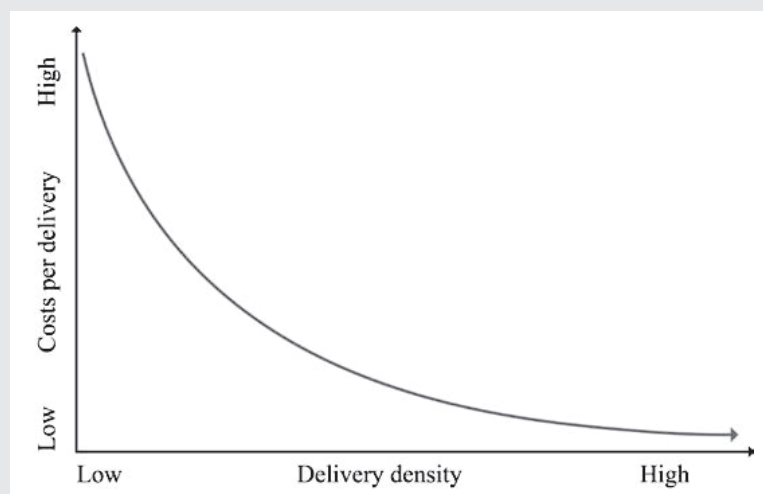

SouRcE: Boyer, Prud'homme \& Chung, 2009

business decisions. The importance of adequate planning of time intervals is visible within Picture 2.

Picture 2 shows average costs per delivery and the delivery density, i.e. the number of deliveries within a certain territory. The average costs decrease with the increase in the number of deliveries in the area serviced by the delivery company. The delivery density is one other factor that influences the decision of the retailer weather to perform the delivery by itself or to outsource that function. In case of high density, own car park can be used more efficiently. In the opposite situation, it is more efficient to outsource the delivery function onto the 3PL providers (third-party logistics providers or outsourced help). The source of 3PL provider efficiency is to perform the deliveries for a multiple number of retailers, thus increasing the delivery density. Small companies which are not able to obtain a higher delivery density, due to reasons of bad promotion strategy or limited transport capacities, are faced with high average costs. In such situation, these companies are not able to compete in the long run with the better organized and positioned players, without the financial aid of other subjects or the change of the business strategy.

Decisions that need to be taken before the design of the time intervals are: (Agatz, Campbell, Fleischmann \& Savelsbergh, 2008).

- The duration of the time intervals;

- Overlapping of the time intervals;

- The number of time intervals;

- Price of delivery.

The mile per buyers decreases with the increase of the length of the time interval (Boyer, Prud'homme \& Chung, 2009). The reason for such an occurrence 
is the servicing of a smaller number of clients in one hour then in the time interval of two hours. The length of the time interval affects the customer service and the flexibility of delivery, where shorter time intervals lead to the increase of customer satisfaction, but also to the increase of delivery costs. Overlapping of the time intervals eases the business for courier services, increasing flexibility, while routing vehicles and using the capacity of the transport vehicles. The efficiency of overlapping can be noted in case when two buyers with addresses in the same street are present in two different time intervals, between $2 \mathrm{PM}$ and $4 \mathrm{PM}$ and $4 \mathrm{PM}$ and 6PM. In such a situation, by opening an additional time interval, from 3PM to 5PM, which overlaps with the existing two, it is possible to service the stated buyers in one row, instead of two, which lowers social issues and issues connected with the environmental protection (Hong \& Shin, 2018). In case of a greater number of intervals the costs per delivery can be increased since the same territory is serviced several times a day, with the empty slots within the transport vehicles. The number of deliveries per interval can vary significantly, which is influenced by the part of the day included within the interval. The regional differentiation of time intervals leads to significant savings compared to the strategy of the entire range of time intervals in the given region (Agatz, Campbell, Fleischmann \& Savelsbergh, 2008). The fee for the delivery depends on the location of the buyer, the size of the delivery and the time interval of the delivery.

\subsection{The delivery in the absence of the receiving party}

In case of delivery in the absence of the receiving party the presence of the buyer at the address at the time of delivery is not demanded. The delivery can be performed both at the location where the buyer lives, as well as the location near the buyer's home. The forms of the delivery in the absence of the receiving party are: (Allen, Thorne \& Browne, 2007)

- Receiving boxes- these boxes are attached to the wall of the buyer's home. One type of boxes is inserted during the construction of the house, or it can be inserted later on, but with more extensive work done. This type of boxes can have three kinds of chambers, for products which demand no special storing conditions, with temperature settings and for frozen products. The other type of boxes are only connected or attached to the wall of the house without any structural changes on the wall. In order to open the box it is needed to insert a code. The notification of the buyer about the received goods is performed by e-mail or telephone (Fernie \& Sparks, 2014).

- Delivery boxes- this type of boxes are filled with goods within the warehouse of the sender or the seller and are delivered sealed to the buyer's address. They are owned by the retailer or the delivery service. At the address of the buyer the box is temporarily connected to a wall using the sealing device which is available right next to the space reserved for the box. After the goods are taken from the box, the buyer can leave the box empty or place in it the goods intended to be returned. The box shall be collected by the supplier when it comes especially for the box or during the next delivery (Zenezini, Lagorio, Pinto, Marco \& Ruggero, 2018).

- The systems of controlled approach-Some zones can have a limited access, such as a backyard, a house or a flat. These zones are equipped with devices which need a code to be unlocked. The access is enabled by the codes known only to the supplier, which are entered into the device positioned at the front door. The supplier receives the codes along with the package or they are sent to him via message. In that manner, the access is enabled to the supplier of that zone and the delivery can be made. When the supplier exits the area, the system is locked again.

- Check points for collecting the orders- This type of points can be located in a near-by post office, a retail object or at the gas station. Within the stated objects, employees can perform the transfer of the delivery to the buyer, once it comes to pick it up. The working hours are usually of the same length as the working hours of the very objects. Up to this point, the goods are delivered by the retailer or the supplier. Upon receiving the order, the buyer is informed by e-mail or by telephone. In accordance with the company, the owner of the check point, the buyers can have the possibility to deliver the shipment from the check point to their home address.

- Lockers-constructed out of several receiving boxes. The locations where they are usually found are in the vicinity of the buyer's home, at places such as buildings and parking slots, but can also be within the work places. The buyers usually do not have their own, personal locker. These lockers are rather used by multiple entities, since they are equipped with electronic locks which are usually 
opened by using a code. The information on the delivery receipt is sent by a message via e-mail or telephone. The message contains the number of the box, the location as well as the code to open the locker. These lockers can be used by one or several delivery companies.

- Neighbors- it is needed that a buyer fills out a form in some of the business units of the courier service and within it to determine which neighbor shall receive the delivery instead of the buyer. It is possible to determine several neighbors, with the list of delivery attempts time tables in case the previous person from the list is not currently present within the address. The information on the delivery receipt, which contains the data on the neighbor who has collected the delivered goods are passed over by leaving a card with the data within the post box, via e-mail or by telephone.

The solutions which enable a safe delivery in the absence of the receiving party are the most profitable (Punakivi, Yrjölä \& Holmström, 2001). The profitability can be seen in maintaining the costs at the normal level due to routing the vehicles more easily, by better using the capacities of the maintenance vehicles, greater flexibility of more narrow time intervals and the non-existence of re-setting the delivery due to the absence of the receiving party. Also, the influence onto the environment is positive, since the mileage passed by the couriers is lowered, and thus the emission of the CO2 as well (Van Duin, Wiegmans, van Arem \& van Amstel, 2019). Besides the stated, the satisfaction of the customers with the lockers is also important. Some $95 \%$ of the locker users are satisfied with the selection of this type of delivery (Lemke, Iwan, \& Korczak, 2016).

\section{THE AMAZON CASE STUDY}

Amazon.com is a multinational company with headquarters in Seattle, USA. The company was established in 1994 by Jeff Bezos, during the time of the internet boom. It has started business as an on-line book shop. The delivery of the bought articles within the company web page was performed by courier services such as UPS. In May 1997, the company has emitted its first package of stocks by an IPO, at the price of $18 \$$ per share, and at that moment it becomes the stock listed company and gains the NASDAQ symbol AMZN (Kawamoto, 1997). In 2018, the company starts the program of goods home delivery and buys 20.000 vans to perform the tasks. The total turnover in 2018 was 232 billion\$, while the number of employees at the same year grew to a total of 647.500 people (Alberg, 2019).

\subsection{The company business portfolio}

During the years, Amazon.com has extended its business to other areas as well. Besides the internet sales, the activities include logistics, 3PL services, ICT, digital contents and publishing. Apart from selling goods of their own property, Amazon.com offers the possibility to other companies as well to sell their goods directly by using the Amazon platform, where the seller uses its account to perform sales and Amazon does the total logistics, from the moment the goods arrive at the warehouse to the buyer's address (Alberg, 2019). The costs calculated in the fee that Amazon charges to the seller-partner are the costs of warehouse space and performing the order delivery.

Amazon Prime is the subscription program, created in 2015, where users become members by paying an annual fee of $119 \$$ or a monthly fee of $12.99 \$$. The membership bears with itself great advantages of buying and delivery. The delivery on the next day for Prime membership is available within USA regardless of the minimum shopping value or additional fees. For the delivery in two days there are more than 100 million different products available while the next day delivery ranges around 10 million products. In 2019, the membership holders were introduced to Amazon Day, the option to schedule the delivery, where buyers themselves determine the day and the time of delivery. The trend on the global logistics market is to try to enable a profitable delivery during the same day. Amazon follows that trend and is entering the race with other retailers wanting to be one of the first which shall enable the same day delivery as a standard option. Through Prime membership the delivery during the same day is free of charge for orders greater then $35 \$$.

Amazon Prime Now offers the possibility to shop and deliver 10.000 different products from electronics, to household appliances and groceries. The users of the Prime Now services are exclusively Amazon Prime members. The offer includes restaurant and local shops delivery. The delivery is performed during the same day, in the period of two hours from setting the order in all areas where there is a possibility to deliver goods and the delivery is free of charge. The delivery is included within the Amazon Prime membership and is not paid additionally for orders above 
$35 \$$ without taxes, while for orders lesser than $35 \$$, it charges $4.99 \$$. The delivery during one hour is available in only certain areas defined by the postal numbers with the fee of $7.99 \$$ per order. In case of grocery delivery, the delivery is performed directly from the Whole Food shops (Green, 2019).

Amazon Fresh is the service of delivering groceries within chosen cities. Amazon Prime membership can use the advantages of this service with the additional expense of $14.99 \$$ per month. The articles ordered via Amazon Fresh are available for home delivery during the day or the next day, depending on the time when the order is made. Also, dependent on the postal number, there is an offer of the possibility to deliver goods during the next hour or two. The delivery is performed from the central warehouse, and not from the Whole Foods stores (Green, 2019).

\subsection{Goods home delivery business model}

The delivery can be performed on its own or by using a $3 \mathrm{PL}$ provider and courier services. Picture 3 shows the stated options available to Amazon for the goods home delivery for a purchase made on-line.

While selling a great number of products on-line, the company also guarantees quick delivery to the buyers. That is the reason behind the constant efforts of Amazon to use the new business models in order to increase the efficiency of delivery and the gain a greater control over the last part of the delivery path towards the end user. When delivery is performed by the company itself, Amazon uses its own network of couriers working full time. However, in order to increase the number of options and to decrease costs, a Delivery Service Partner program has been created, which along with Amazon Flex, gives the company and even greater range of possibilities of performing delivery.

Amazon Flex offers the possibility to physical entities to deliver shipments by using own vehicles. This is a sort of crowdsourcing platform, where independent couriers take on the job by using the Amazon Flex application within their mobile devices. The application enables all, from scanning the packages in the package collection center, determining the routes to follow, right up to the final confirmation that the package has been received, which also includes taking photos of delivered parcels to home addresses. Besides the orders from the site Amazon.com, Amazon Flex covers orders generated by the two-hour delivery services Amazon Prime Now and Amazon
Picture 3. Goods home delivery

business model by Amazon

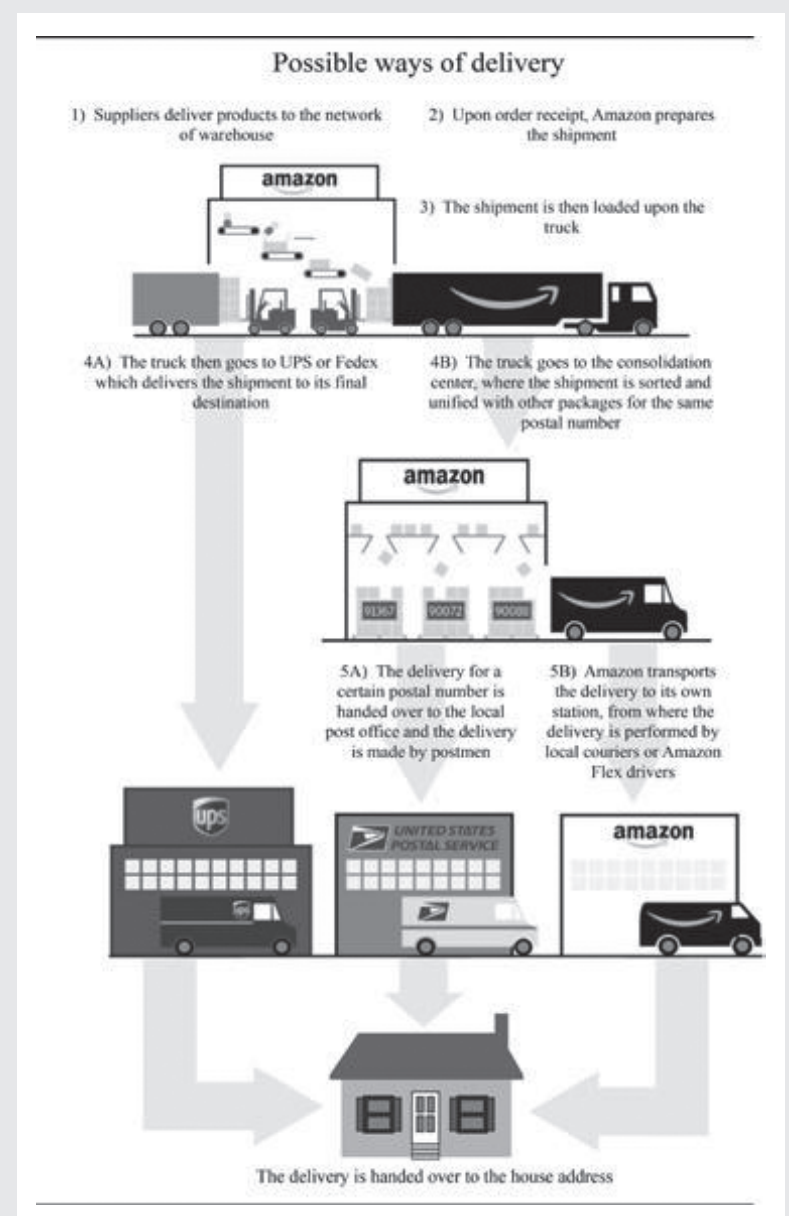

Source: Bensinger \& Stevens, 2019

Fresh. Fuel and all other costs connected with performing this type of business are bared by the very owner of the vehicle. Amazon Flex is only a part of the company logistics network.

The program of supplier partners helps entrepreneurs to start and lead smaller courier campaigns which deliver orders bought via the site Amazon. com. Amazon cooperates with entrepreneurs which are called partners for the delivery service and pays them for the services of delivering parcels, simultaneously offering discounts for vehicles, uniforms, fuel, insurance etc. Delivery is performed by the branded Mercedes Benz vans. All drivers are obliged to wear the same uniform and own the same branded fleet of vehicles. The fleet consists of maximum of 40 vehicles, and the number of employees does not surpass 100 . The program is not a substitute for Amazon Flex, but 
rather a logistics appendix to the network. Performing delivery is done in the presence or absence of the buyer, at the buyer's address or some other address. The delivery in presence is the main type of delivery where couriers from Amazon hand over the shipment to the buyers personally. In case of the delivery in absence, lockers for taking over the deliveries are used (Amazon Locker and The Hub).

Amazon locker is a suitable way to perform the delivery. In order for the buyers to use these lockers, they must have an account on Amazon.com. The location of these check points is near the buyers' address and positioned within popular spots such as shops and pharmacies, where the delivery can be picked up without the additional expense (Gebel, 2019). The Amazon couriers deposit the package into one of the drawers of the locker, out of which the buyers can take over the parcel in a time space which is best convenient for them, bearing in mind the working hours of the object where the lockers are positioned. Due to the physical characteristics of the locker, the size and weight of the shipment are limited. After the delivery has been performed, Amazon sends a six-digit code for opening the locker. Once entering the code on the screen of the locker, the doors of the locker open and the shipment can be taken over. The deadline for taking over the parcel is three days. If the parcel is not taken over in that time period, the shipment shall be returned and the buyer shall be given back the money.

Another convenient way to make a delivery is The Hub. It is similar to the previously mentioned locker and functions in the same way, with the exception that shops are located in residential buildings and complexes. The shipments can be from any sender, not just Amazon. The type of the transport vehicle used for deliveries depends on the program of delivery, so these can be different types of vehicles, vans, pickup trucks, bicycles, drones, robots. Most used is the Mercedes Benz Sprinter and the specially designed Spartan van, followed by private cars and bicycles, while drones and robots are at the testing phase (Alberg, 2020).

\section{CONCLUSION}

Urban logistics is not at all simple and in order to be adequately performed, every aspect of its functioning and the influence of different factors must be taken into consideration. Since by definition, delivery assumes the transport of goods from the warehouse in the vicinity or at the outskirts of the city to the address of the final buyer, it represents a finishing act in goods movement through the entire logistics chain. Costs can be up to a third of total logistics costs which speaks by itself about the complexity of the delivery operations. In order for the costs of delivery to be controlled and potentially lower, the delivery must be performed in an efficient way. For offering the satisfactory performance, it is needed to create an adequate strategy and design the operative activities.

The contemporary buyer does not have the same habits as the buyer from a decade or two ago. The surroundings in which the buyer lives in and the it's life style lead to the development of buyer needs and wants. The buyers desire to spend as little time possible on activities of shopping and taking over the bought goods is noticeably present. After having performed the analysis within the paper, two needs are expressed when it comes to product delivery. The first need is to deliver the product as quick as possible, and the other to deliver it at a certain time. The degree of the IT advances goes hand in hand with the intentions of the companies, so the companies are able to respond cost -effectively to the needs and wants of the buyers. Only cost efficient delivery can pay out in the long run.

The case study analysis in the paper indicates that Amazon is constantly improving its logistics performance through the development of existing solutions and by creating new ones. The characteristic of this company is the possibility to perform delivery quite fast, in a reliable way and with acceptable costs, with the positive answer by the buyers in form of repeated transactions which are rising year in, year out. The above mentioned are the main results of the paper analysis. Dealing only with secondary data and not performing a primary research is the main paper shortcoming. Finally, since the initiatives for the development of new technologies and software solutions are constantly present their other aspects and practical research shall be the subject of our future surveys and papers to come. 
1. Agatz, N, Campbell, A., Fleischmann, M. \& Savelsbergh, M. (2008). Challenges and opportunities in attended home delivery. in Golden B., Raghavan S, Wasil E., editors. Operations research/computer science interfaces series: vol. 43. The vehicle routing problem: Latest advances and new challenges, Boston, US: Springer Science+Business Media LLC, 379-396.

2. Agatz, N., Campbell, A., Fleischmann, M. \& Savelsbergh, M. (2008). Time Slot Management in Attended Home Delivery. Transportation Science, 45(3), 435-449. doi: 10.1287/trsc.1100.0346

3. Alberg, T. (2019, January 1). Amazon 2018 annual report. Amazon info. Retrieved from: https:// ir.aboutamazon.com/static-files/0f9e36b1-7e1e-4b52be17-145dc9d8b5ec

4. Alberg, T. (2020, March 2). Help grow your business by fulfillment by Amazon. Amazon info. Retrieved from: https://services.amazon.com/fulfillment-byamazon/benefits.html

5. Alberg, T. (2020, March 6). Hub deliveries. Amazon info. Retrieved from: https://www.amazon.com/ $\mathrm{b}$ ?ie $=$ UTF8\&node $=17337379011$

6. Allen, J., Thorne, G. \& Browne, M. (2007). Good practice guide on urban freight transport. Zoetermeer, The Netherlands: BESTUFS.

7. Banes, T. (2020, March 5). Help grow your business with fulfillment by Amazon. Amazon info. Retrieved from: https://www.amazon.com/Prime-FREE-SameDay-Delivery $/ \mathrm{b}$ ?ie $=$ UTF8\&node $=8729023011$

8. Baum, L., Assmann, T. \& Strubelt, H. (2019). State of the art-Automated micro-vehicles for urban logistics. IFAC PapersOnLine, 52(13), 2455-2462. doi: 10.1016/j. ifacol.2019.11.575

9. Bensiger, G. \& Stevens, L. (2019, March 5). Amazon's newest ambition: competing directly with UPS and FEDEX. The Wall Street Journal. Retrieved from: https://www.wsj.com/articles/amazonsnewest-ambitioncompeting-directly-with-ups-andfedex-1474994758

10. Boyer. K., Prud'homme, A. \& Chung, W. (2009). The last-mile challenge: evaluating the effects of customer density and delivery window patterns. Journal of Business Logistics, 30(1), 185-201. doi: 10.1002/j.21581592.2009.tb00104.x

11. Božić, V., Aćimović, S. (2019). Marketing logistika. Beograd: CIDEKOF.

12. Crainic, T. \& Montreuil, B. (2016). Physical internet enabled Hyper-connected City Logistics. Transportation Research Procedia, 12, 383-398. doi: 10.1016/j.trpro.2016.02.074

13. Dell'Amico, M. \& Hadjidimitriou, N. (2012). Innovative Logistics Model and Containers Solution for Efficient Last Mile Delivery. Procedia - Social and Behavioral Sciences, 48, 1505-1514. doi: 10.1016/j. sbspro.2012.06.1126

14. Fernie, J. \& Sparks, L. (2014). Logistics and Retail Management: Emerging issues and new challenges in the retail supply chain. London, UK: Kogan page.

15. Foltyński, M. (2014). Electric fleets in urban logistics. Procedia-Social and Behavioral Sciences, 151, 48-59. doi: 10.1016/j.sbspro.2014.10.007

16. Gebel, M. (2019, May 30). What is Amazon locker?' : everything you need to know about Amazon's convenient delivery pick up system. Business Insider. Retrieved from: https://www.businessinsider.com/ what-is-amazon-locker

17. Ghajargar, M., Zenezini, G. \& Montanaro, T. (2016). Home delivery services: innovations and emerging needs. IFAC-PapersOnLine, 49(12), 1371-1376. doi: 10.1016/j.ifacol.2016.07.755

18. Green, D. (2019, February 1). How to use Amazon Prime Now. Business Insider. Retrieved from: https:// www.businessinsider.com/how-to-use-amazonprime-now-2019-2

19. Green, D. (2019, February 2). How to use Amazon Fresh. Business Insider. Retrieved from: https:// www.businessinsider.com/how-to-use-amazonfresh-2019-2

20. Hong H. \& Shin K. (2018). A Study on the Restructuring and Cavitation of the Data-based Pick-up and Delivery Business. The Asian Journal of Shipping and Logistics, 34(1), 43-50. doi: 10.1016/j. ajsl.2018.03.006

21. Kawamoto, D. (1997, May 15). Amazon.com IPO skyrockets. C-Net. Retrieved from: https://www.cnet. com/news/amazon-com-ipo-skyrockets/

22. Köhler, C. \& Haferkamp J. (2019). Evaluation of delivery cost approximation for attended home deliveries. Transportation Research Procedia, 37, 6774. doi: 10.1016/j.trpro.2018.12.167

23. Lemke, J., Iwan, S. \& Korczak, J. (2016). Usability of the parcel lockers from the customer perspective- the research in Polish Cities. $2^{\text {nd }}$ International Conference Green Cities- Green Logistics for Greener Cities, Szczecin, Poland. 272-287.

24. Lim, S., \& Winkenbach, M. (2019). Configuring the Last-Mile in Business-to-Consumer E-Retailing. California Management Review, 61(2), 132-154. doi: 10.1177/0008125618805094

25. Madlberger, M. \& Sester, A. (2005). The Last Mile in an Electronic Commerce Business Model - Service Expectations of Austrian Online Shoppers. ECIS 2005 Proceedings, 899-910. 
26. Punakivi, M., Yrjölä, H. \& Holmström, J. (2001). Solving the last mile issue: reception box or delivery box? International Journal of Physical Distribution and Logistics Management, 31(6), 427-439. doi: 0.1108/09600030110399423

27. Van Duin, R. de Goffau, W., Wiegmans B., Tavasszy, L. \& Saes, M. (2016). Improving home delivery efficiency by using principles of address intelligence for B2C deliveries. Transportation Research Procedia, 12, 1425. doi: $10.1016 /$ j.trpro.2016.02.006
28. Van Duin, R., Wiegmans, B., van Arem, B. \& van Amstel, Y. (2019). From home delivery to parcel lockers: A case study in Amsterdam. The $11^{\text {th }}$ International Conference on City Logistics, Dubrovnik, Croatia. 88-96.

29. Zenezini, G., Lagorio, A., Pinto, R., Marco, A. \& Ruggero, A. (2018). The Collection and Delivery Points Implementation Process from the Courier, Express and Parcel Operator's Perspective. IFACPapersOnLine, 51(11), 594-599. doi: 10.1016/j. ifacol.2018.08.383

\section{Apstrakt:}

\section{Logistički aspekti dostave robe na kućnu adresu: slučaj kompanije Amazon}

\section{Slobodan Aćimović, Veljko Mijušković,} Nikola Milošević

\begin{abstract}
Adekvatno upravljanje logističkim aktivnostima bitno je za efikasnost svih poslovnih aktivnosti jednog preduzeća. Dostava robe na kućnu adresu kao koncept je dobila na značaju razvojem interneta i elektronske maloprodaje. $\mathrm{U}$ poslednjoj deceniji, usled sve intenzivnijeg informaciono-tehnološkog razvoja ona se nameće kao aktuelnost u savremenom logističkom poslovanju. U okviru ovog koncepta bitna je vremenska dimenzija koja se naglašava upravo zbog zahteva savremenog stila života. Prosečan kupac želi više slobodnog vremena, pa mu mogućnost dostave značajno skraćuje vreme potrebno za kupovinu, što vodi preferiranju internet prodavaca koji vrše dostavu kao standardni deo svoje ponude. Razmatranje logistič-
\end{abstract}

kih aspekata pomenutog koncepta i njegova realizacija na primeru konkretnog preduzeća (Amazon) osnovni su predmet analize u radu. Cilj rada je da pokaže da savremeno tržište dostave pored postojećih velikih igrača, karakteriše i ulazak preduzeća u nastajanju, koja se razvijaju kao rezultat preduzetničkih inicijativa. Osobenost angažovanja preduzetnika je razvoj nove ideje oličene u poslovnoj filozofiji ili novim tehnoloških zamislima, bilo da se radi o rešavanju postojećih izazova ili o uviđanju i iskorišćavanju novih tržišnih prilika.

\section{Ključne reči: logistika, dostava, aplikacija, vremenski} intervali, Amazon.

\section{Kontakt:}

Slobodan Aćimović, slobodan.acimovic@ekof.bg.ac.rs Veljko Mijušković, mijuskovic@ekof.bg.ac.rs Ekonomski fakultet, Univerzitet u Beogradu, Kamenička 6, Beograd

Nikola Milošević, nikolamilosevic1@yahoo.com Industrijski kompleks Trepča 